Archive for

Organic Chemistry

Arkivoc 2020, part viii, 161-175

\title{
Rearrangement and cyclisation reactions on the 1-arylpyrrol-2-iminyl - 2-aryliminopyrrol-1-yl radical energy surface
}

\author{
Scott Borthwick, ${ }^{a}$ Jonathan Foot, ${ }^{a}$ Maria leva, ${ }^{a}$ Hamish McNab, ${ }^{\# a}$ Lilian McNab, \\ Emma J. Rozgowska, ${ }^{a}$ and Andrew Wright ${ }^{a}$ \\ ${ }^{a}$ School of Chemistry, The University of Edinburgh, West Mains Road, Edinburgh EH9 3JJ. UK \\ ${ }^{b} 6$ Torphin Road, Edinburgh EH13 OHW, UK \\ Email: Lilian.McNab@gmail.com
}

Received 06-01-2020

Accepted $11-29-2020$

Published on line $12-28-2020$

\section{Abstract}

Independent generation of the iminyl $(X=N)$ and pyrrol-1-yl $(X=N)$ radicals by flash vacuum pyrolysis of the corresponding oxime ether and $\mathrm{N}$-(dimethylamino) compound, respectively, provides two regioisomeric pyrrolo1,2-a]quinoxalines compounds. This shows that the radical species interconvert via the spirodienyl moeity at high temperatures. Corresponding generation of the pyrrol-1-yl $(X=C H)$ radical gives the pyrrolo[1,2-a]quinoline as the only cyclised product. In this case, DFT calculations suggest that direct cyclisation of the pyrrol-1-yl takes place, rather than formation of the spirodienyl species and exclusive migration of the $\mathrm{C}-\mathrm{N}$ bond.

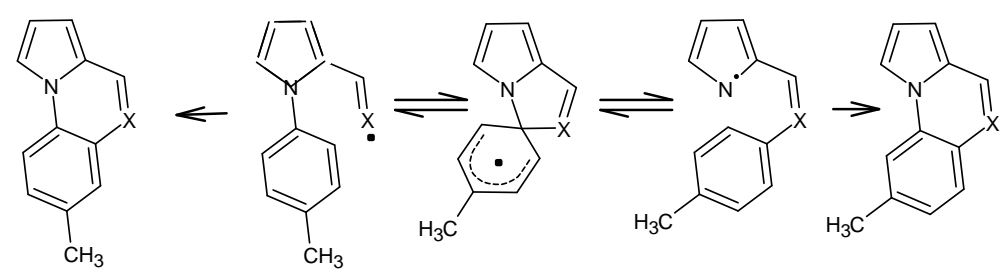

Keywords: FVP, radicals, pyrroles, fused heterocycles 


\section{Introduction}

In previous papers we have explored the cyclisation reactions of iminyl radicals, generated in the gas-phase under flash vacuum pyrolysis (FVP) conditions. ${ }^{1}$ In some cases, e.g. aryliminoiminyls, these reactions are dominated by ipso-attack and rearrangement via spirodienyl radicals (Scheme $1, X=N$ ), ${ }^{2}$ leading to mixtures of cyclisation products. The mechanism was supported by ${ }^{15} \mathrm{~N}$-labelling experiments. ${ }^{3}$ However, corresponding rearrangements are not observed for arylvinyliminyls ${ }^{4}$ (Scheme $1, X=C H$ ), so the products must be formed either by direct cyclisation or by formation of the spirodienyl intermediate followed by exclusive migration of the C-N bond.

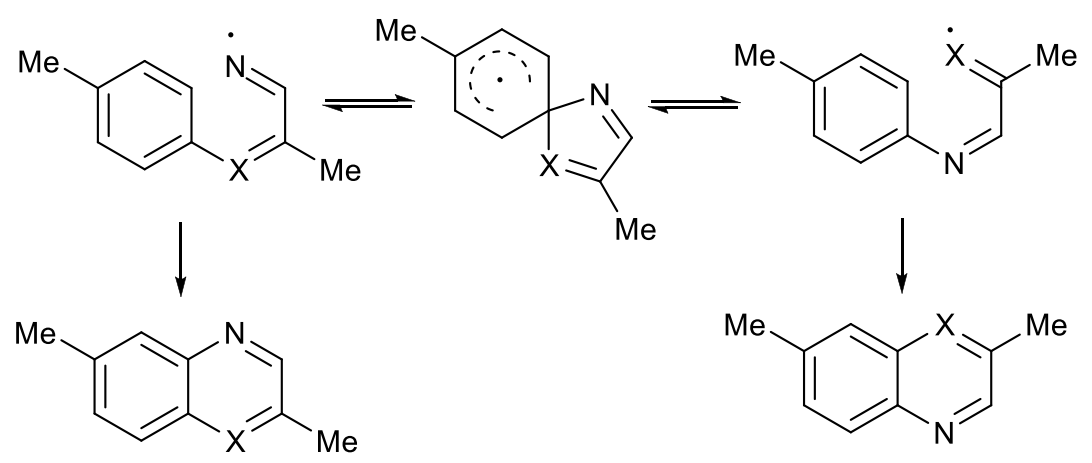

Scheme 1. Radical cyclizations forming quinoxalines.

The aims of the work reported here are summarised in Scheme 2. First, we hoped to generate the iminyl 1 $(\mathrm{X}=\mathrm{N})$ by the standard method involving FVP of the corresponding oxime ether. With two fused 5-membered rings, the spirodienyl intermediate $\mathbf{3}(X=N)$ is necessarily more strained than its analogue in Scheme 1 but, if rearrangement were to take place, generation of the pyrrol-1-yl radical $2(X=N)$ would provide complementary entry to the energy surface. However, almost nothing is known about the synthetic organic chemistry of pyrrol-1-yl radicals except that a dimeric product is obtained when a vast excess of pyrrole is decomposed in the presence of $t$-butyl peroxide. ${ }^{5}$ Tetraarylpyrrol-1-yl radicals have been characterised by EPR spectroscopy, ${ }^{6}$ and more recently the pyrrol-1-yl radical itself has been implicated in UV photodissociation experiments ${ }^{7}$ and its electron affinity has been measured. ${ }^{8}$ Meanwhile, considerable theoretical work on the structure of the pyrrol-1-yl radical has been carried out. ${ }^{8-13}$

In the context of the present work, inventing a general FVP precursor to pyrrol-1-yl radicals for use in synthetic and mechanistic chemistry was therefore a major target. With a precursor for $\mathbf{2}(X=N)$ in place, the strategy was extended to the case of the 2-styrylpyrrolyl $\mathbf{2}(\mathrm{X}=\mathrm{CH})$, though no attempt was made to create a route to the vinyl radical $(1, X=C H)$. Finally, the mechanistic details of the rearrangement processes were analysed by DFT calculations at the B3LYP/cc-pVDZ level. 


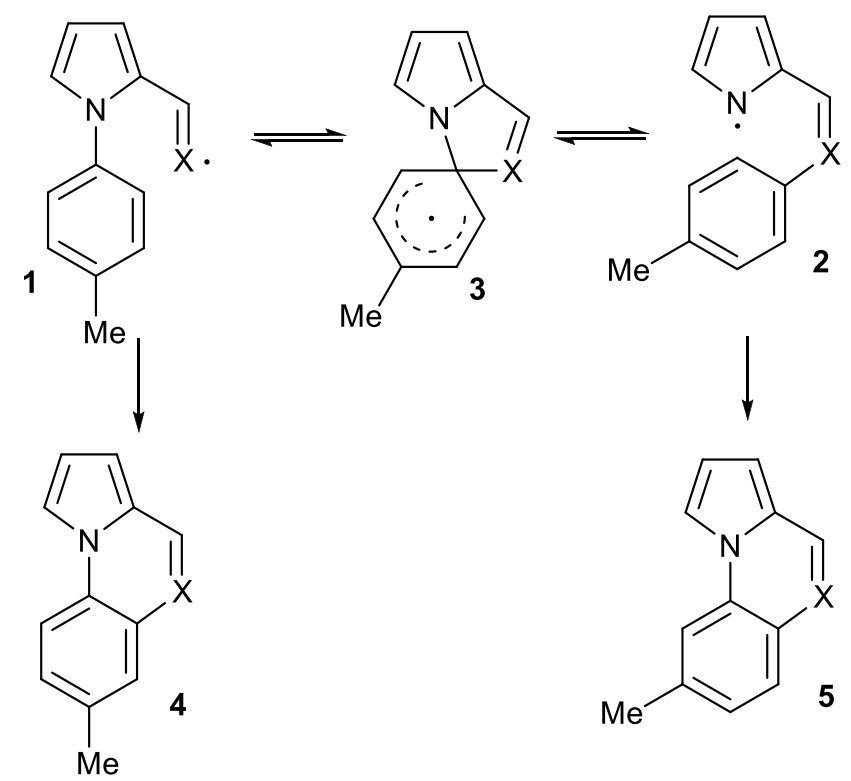

Scheme 2. Formation of pyrrolo[1,2-a]quinolines and quinoxalines.

\section{Results and Discussion}

The iminyl precursor 8 was made by the route shown in Scheme 3. Vilsmeier formylation of 1-(p-tolyl)pyrrole 6 gave, in our hands, a mixture of the 2- and 3-formyl isomers, from which the 2-isomer 7 was obtained by recrystallisation (70\%). ${ }^{14}$ Condensation with $O$-methylhydroxylamine gave the oxime ether $8(83 \%)$ as a mixture of $E$ - and $Z$-isomers which were not separated.

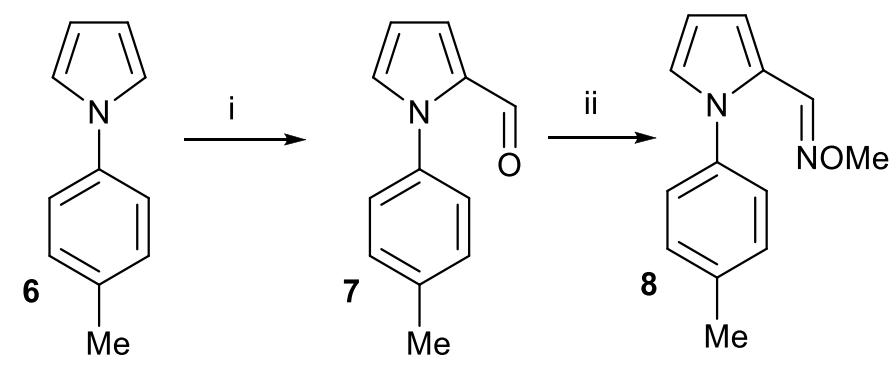

Scheme 3. Preparation of the oxime ether 8. Reagents and conditions: (i) $\mathrm{DMF} / \mathrm{POCl}_{3}, 2{ }^{\circ} \mathrm{C}$; (ii) $\mathrm{MeONH}_{2}$ EtOH, reflux.

In order to design a precursor for the pyrrol-1-yl radicals 2, it was essential for the molecule to have a weak N-Z bond which would cleave homolytically upon pyrolysis. Often we have used benzyl or allyl groups for this purpose, ${ }^{1}$ but it is known that $\mathrm{N}$-benzyl- or $\mathrm{N}$-allyl- pyrrole undergoes rearrangement by 1,5 -sigmatropic shifts rather than radical cleavage. ${ }^{15}$ However, we have also shown that hydrazones are useful generators of iminyl radicals, ${ }^{1,2}$ and so the possibility of using derivatives of $\mathrm{N}$-(dimethylamino)pyrrole 9 was investigated. FVP of $N$-(dimethylamino)pyrrole $\mathbf{9}$ itself showed the formation of pyrrole 10, as well as some unidentified products, which suggests that homolysis could be followed by hydrogen atom capture, a standard reaction of 
aminyl and phenoxyl radicals (Scheme 4). ${ }^{1}$ The temperature profile of the $\mathbf{9} \rightarrow \mathbf{1 0}$ conversion (Figure 1) shows that temperatures of $800-850^{\circ} \mathrm{C}$ are required to complete the homolysis.

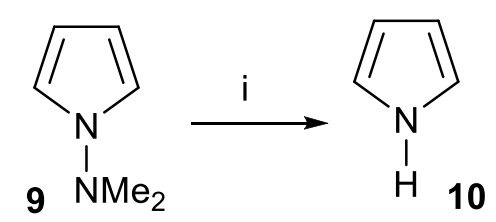

Scheme 4. Pyrolysis of 1-(dimethylamino)pyrrole. Reagents and conditions: (i) FVP, $850^{\circ} \mathrm{C}$.

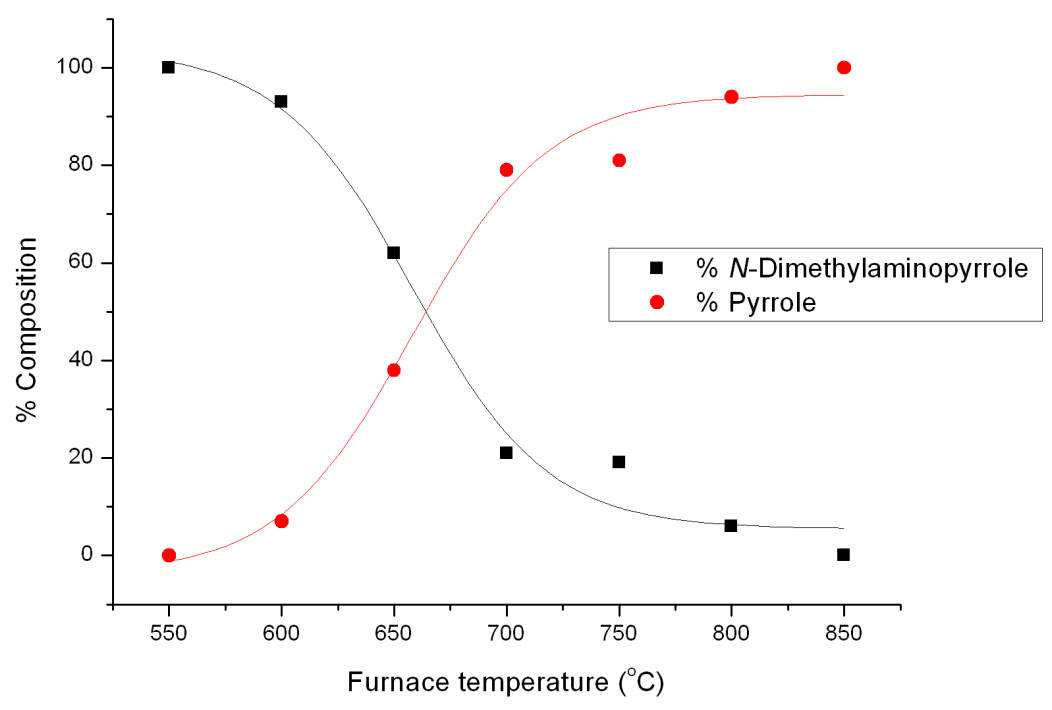

Figure 1. Temperature profile of $\mathbf{9} \rightarrow \mathbf{1 0}$ conversion.

Accordingly, a precursor to $\mathbf{2}(X=N)$ was made, in two steps. First, formylation of $\mathbf{9}$ was carried out by the literature method; ${ }^{16}$ the 2 -formyl isomer 11 was isolated as the major product (52\%) after chromatography, though some of the 3-formyl product 14 was also obtained (12\%). The imine 12 (97\%) was synthesised by condensation with $p$-toluidine (Scheme 5). The precursor to $2(\mathrm{X}=\mathrm{CH})$ was made by Wittig reaction ${ }^{16}$ of the aldehyde 11 with the corresponding ylide which gave the 2-styryl compound 13 (Scheme 5). The corresponding 3-styryl compound $\mathbf{1 5}$ was made similarly by reaction of the 3-formylpyrrole $\mathbf{1 4}$. Only the trans isomers were detected in solution by $n m r\left({ }^{3} \mathrm{~J}, 16 \mathrm{~Hz}\right) \mathrm{FVP}$ of the oxime ether 8 gave two heterocyclic products in essentially equal amounts ( $40 \%$ and $41 \%$ isolated yields), together with small amounts of 1- $p$-tolylpyrrole-2carbonitrile $18(8 \%)$ and 1-p-tolylpyrrole $6(5 \%)$, all of which were separated by chromatography (Scheme 6). The heterocyclic products were identified as 7-methylpyrrolo[1,2-a]quinoxaline 16 and 8-methylpyrrolo[1,2a]quinoxaline $\mathbf{1 7}$ by the NOESY data shown in Figure 2. Compound $\mathbf{1 6}$ is characterised by the correlation of a pyrrole proton at $\delta_{H} 7.86$ (corresponding to $\mathrm{H}-1$ ) with a doublet benzenoid proton at $\delta_{H} 7.82$ (corresponding to $\mathrm{H}-9$ ). Compound 17 is characterised by the correlation of a pyrrole proton at $\delta_{H} 7.91$ (due to $\mathrm{H}-1$ ) with a 'singlet' benzenoid proton at $\delta_{H} 7.68$ (due to $\mathrm{H}-9$ ). 


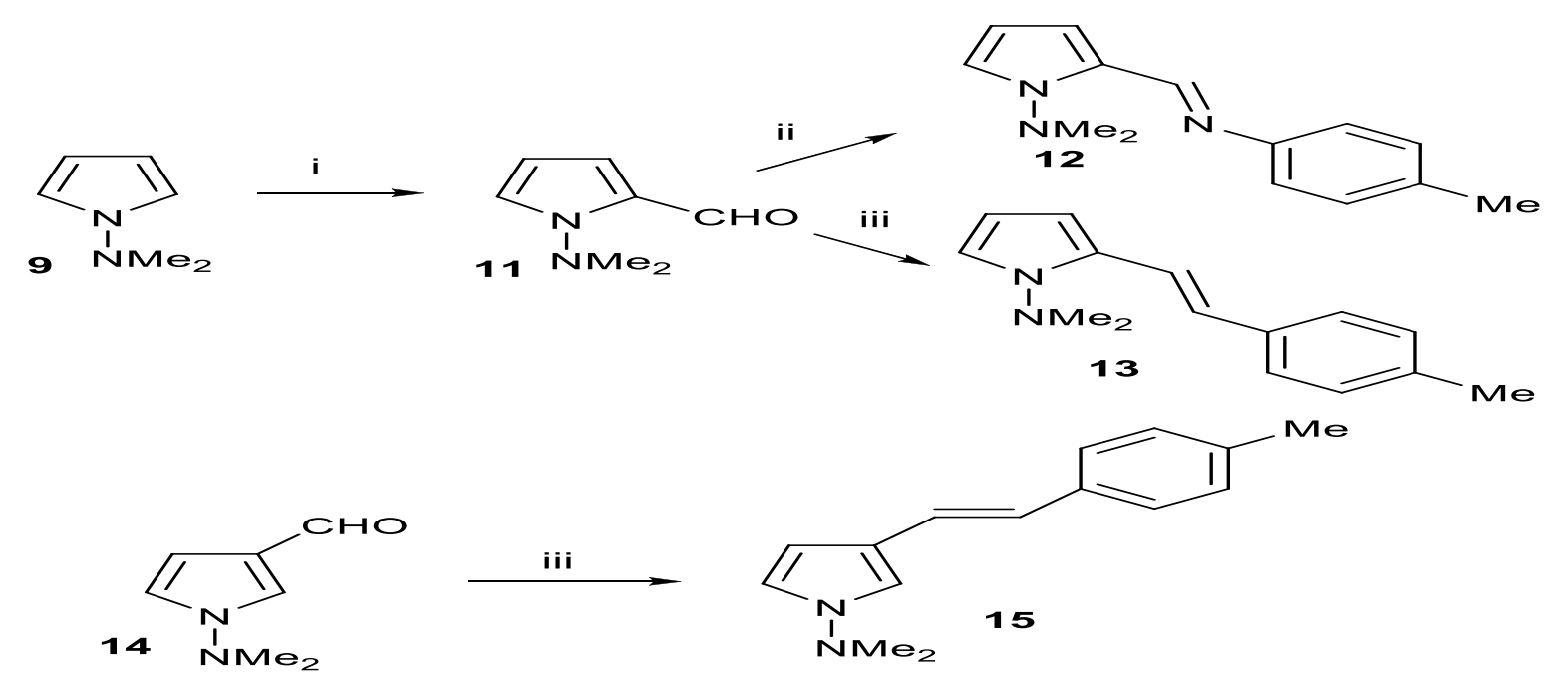

Scheme 5. Preparation of the imine 12 and the styrylpyrroles 13 and 15. Reagents and conditions: (i) $\mathrm{DMF} / \mathrm{POCl}_{3}, 1$,2-dichloroethane, reflux; (ii) $p-\mathrm{MeC}_{6} \mathrm{H}_{4} \mathrm{NH}_{2}$, EtOH, reflux; (iii) $\mathrm{Ph}_{3} \mathrm{P}=\mathrm{CHAr}$, toluene, reflux.

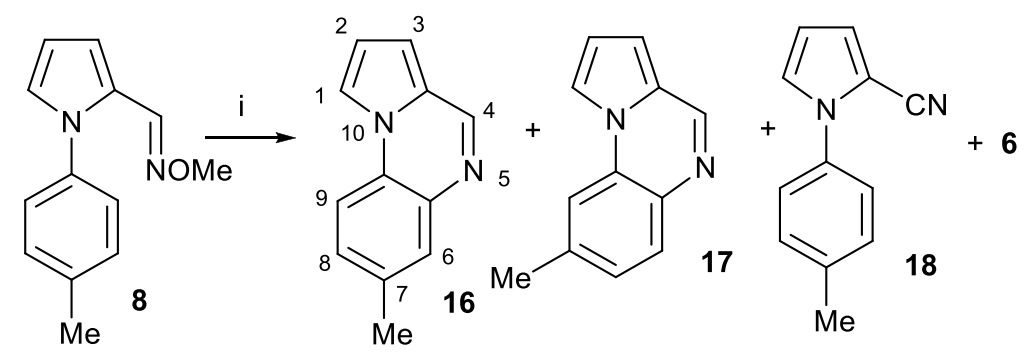

Scheme 6. Products of FVP of the oxime ether 8. Reagents and conditions: (i) FVP, $650{ }^{\circ} \mathrm{C}$.

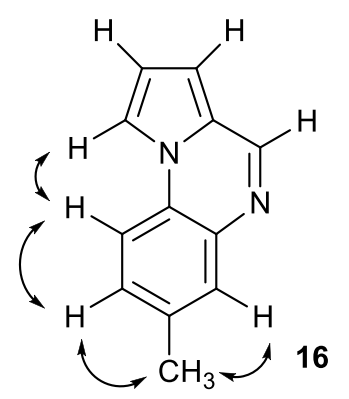<smiles>Cc1ccc2ncc3ccc([TlH])c-3n2c1[13CH2]</smiles>

Figure 2. NOE data for 16 and 17.

The formation and unambiguous characterisation of 16 and $\mathbf{1 7}$ suggests that the iminyl $\mathbf{1}(\mathrm{X}=\mathrm{N})$ is able to undergo ipso-attack to generate the spirodienyl radical $\mathbf{3}(X=N)$ (Scheme 2) which subsequently rearranges to the two regioisomeric products. However, it is unclear whether interconversion via the spirodienyl is complete or whether this reaction mode competes with direct cyclisation at the ortho-position. 


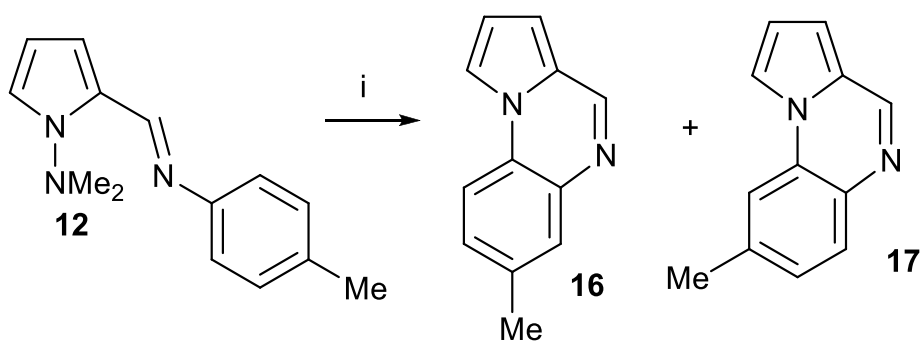

Scheme 7. Products of FVP of the dimethylaminopyrrole 12. Reagents and conditions: (i) FVP, $800{ }^{\circ} \mathrm{C}$.

More information on this point was gained by FVP of the $\mathrm{N}$-dimethylaminopyrrole 12 at $800{ }^{\circ} \mathrm{C}$ (Scheme 7) which provided the two methylpyrrolo[1,2-a]quinoxalines 16 (23\% of the mixture) and 17 (73\% of the mixture) (4\% of mixture not assigned). First, this provides further evidence that the pyrrol-1-yl radical 2 (X=N) can be generated by this route and that it is capable of cyclisation reactions to provide 6-membered ring products. Second, the formation of the two heterocyclic products $\mathbf{1 6}$ and $\mathbf{1 7}$ shows that at least some cyclisation via the spirodienyl must take place. However, the fact that these products were obtained in unequal ratio (in contrast to the result from FVP of 8 ) is evidence that direct cyclisation must also play a part in the energy surface summarised by Scheme 2 (see later discussion) and provides the major product from the pyrrol-1-yl.

In contrast, FVP of the styryl compound 13 at $750{ }^{\circ} \mathrm{C}$ gave only 8-methylpyrrolo[1,2-a]quinoline 19 (50\% yield) (Scheme 8). NOESY analysis confirmed the structure by correlation of a pyrrole proton with a 'singlet' benzenoid proton (c.f. 17 in Figure 2). In this case E/Z-isomerisation of the alkene 17 is followed by direct cyclisation at the ortho-position, or by spirodienyl formation followed by exclusive migration of the $\mathrm{C}-\mathrm{N}$ bond. Such high regioselectivity has major advantages in the use of pyrrol-1-yl radicals as a synthetic route to unusual pyrrolo[1,2-a]quinolines.

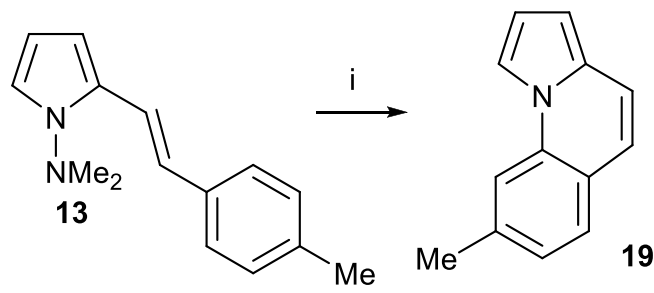

Scheme 8. FVP of the 2-styryl pyrrole 13. Reagents and conditions: (i) FVP, $750{ }^{\circ} \mathrm{C}$.

Only low yields of products could be isolated from FVP of the 3-styryl isomer 15 at $750{ }^{\circ} \mathrm{C}$, which suggests that the 3-substituted pyrrol-1-yl radical has no clear route to products (Scheme 9). The two compounds that were isolated in greatest amounts were the known ${ }^{18}$ deaminated pyrrole 20 (11\%) (c.f. Scheme 4) a product of hydrogen-capture by the pyrrol-1-yl radical and 8-methylpyrrolo[1,2-a]quinoline 19 (5\%). The formation of 8methylpyrrolo[1,2-a]quinoline 19 requires rearrangement of the vinyl group from the 3-position to the 2position of the pyrrole, followed by cyclisation. Such 1,5-shifts are well-known in the thermal chemistry of pyrroles, ${ }^{15}$ and although the rearrangement is not normally quantitative at temperatures as low as $750{ }^{\circ} \mathrm{C}$ in our apparatus, they may well account for the formation of such a minor product (5\%).

8-Methylbenzo $[g]$ indole was tentatively identified in trace amounts from an impure fraction, and is consistent with delocalisation of the pyrrol-1-yl radical to the 2-position, followed by cyclisation. Clearly this is not a favorable process for the initial radical. 


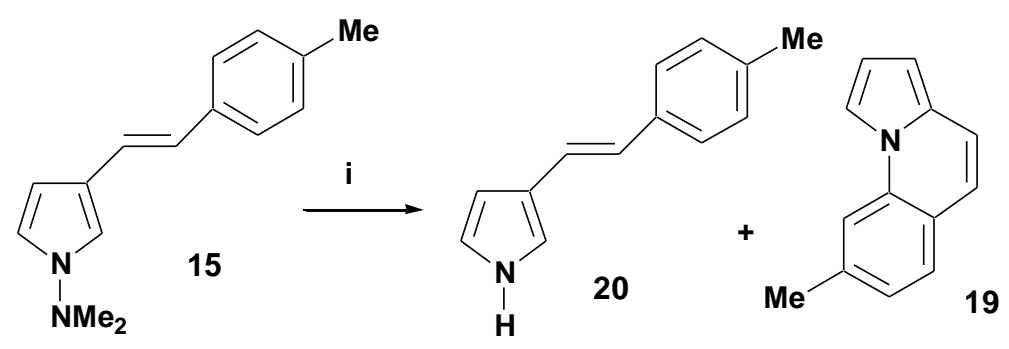

Scheme 9. FVP of the 3-styryl pyrrole 15. Reagents and conditions: (i) FVP, $750{ }^{\circ} \mathrm{C}$.

To summarise the experimental results: independent generation of the iminyl $\mathbf{1}(X=N)$ and of the pyrrol-1yl $2(X=N)$ radicals results in isomeric mixtures of the cyclisation products 7-methylpyrrolo[1,2-a]quinoxaline 16 (i.e. 4, $\mathrm{X}=\mathrm{N}$ ) and 8-methylpyrrolo[1,2-a]quinoxaline 17 (i.e. 5, $\mathrm{X}=\mathrm{N}$ ), though in different ratios from the two precursors. In contrast, generation of the pyrrol-1-yl $2(X=\mathrm{CH})$ provides only 8-methylpyrrolo[1,2a]quinoline 19 (i.e. 5, $\mathrm{X}=\mathrm{CH}$ ). The situation is summarised in Scheme 10, an extension of Scheme 2, in which the iminyl $\mathbf{1}(X=N)$ is potentially in equilibrium with the direct cyclisation intermediate $\mathbf{2 1}(X=N)$ and the spirodienyl radical $\mathbf{3}(X=N)$. Similarly, the pyrrol-1-yl $\mathbf{2}(X=N)$ can equilibrate with its direct cyclisation intermediate $22(X=N)$ and with the spirodienyl $\mathbf{3}(X=N)$.

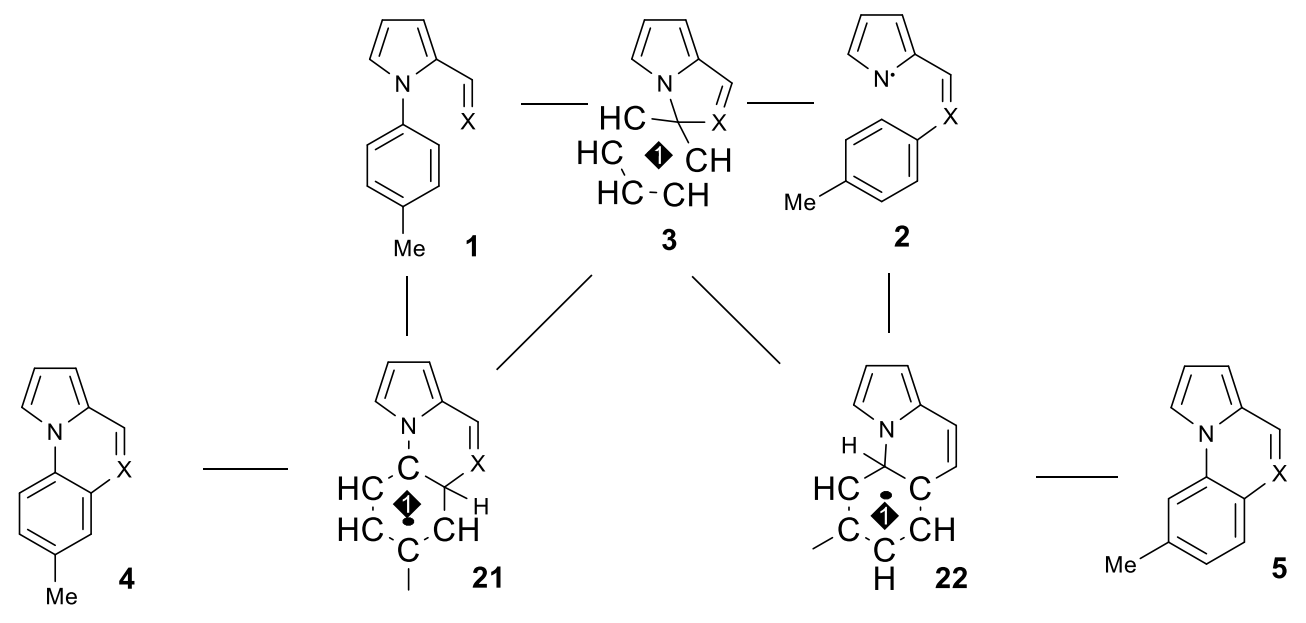

Scheme 10. Radical pathways resulting in equilibration and isomeric products.

The energy surface of the $N$-phenyliminyl corresponding to $\mathbf{1}(\mathrm{X}=\mathrm{N})$ was modelled by DFT calculations (B3LYP/cc-pVDZ) (Figure 3). ${ }^{19}$ These show that the difference in barrier between the iminyl $\mathbf{1}(\mathrm{X}=\mathrm{N})$ and the direct cyclisation intermediate $\mathbf{2 1}(X=N)$ and between the iminyl and the spirodienyl $\mathbf{3}(X=N)$ is $21.5 \mathrm{~kJ} \mathrm{~mol}^{-1}$ in favour of the direct cyclisation. The corresponding difference between the pyrrol-1-yl $2(X=N)$, its direct cyclisation intermediate $22(X=N)$ and the spirodienyl $\mathbf{3}(X=N)$ is $26.6 \mathrm{~kJ} \mathrm{~mol}^{-1}$, again in favour of the direct cyclisation. This suggests that the direct cyclisation is relatively favoured kinetically in the case of the pyrrol-1$\mathrm{yl}$, as found by experiment. Thermodynamically, the spirodienyl $3(X=N)$ lies $40.6 \mathrm{~kJ} \mathrm{~mol}^{-1}$ above the direct cyclisation intermediate 21 [from the iminyl $1(X=N)$ ] and some $59.9 \mathrm{~kJ} \mathrm{~mol}^{-1}$ above the direct cyclisation intermediate 22 [from the pyrrol-1-yl $\mathbf{2}(X=N)$ ]. Again, direct cyclisation from the pyrrol-1-yl is relatively favoured thermodynamically, though it is somewhat surprising that the spirodienyl route can compete at all, given the high relative energies of its intermediate and transition states. 


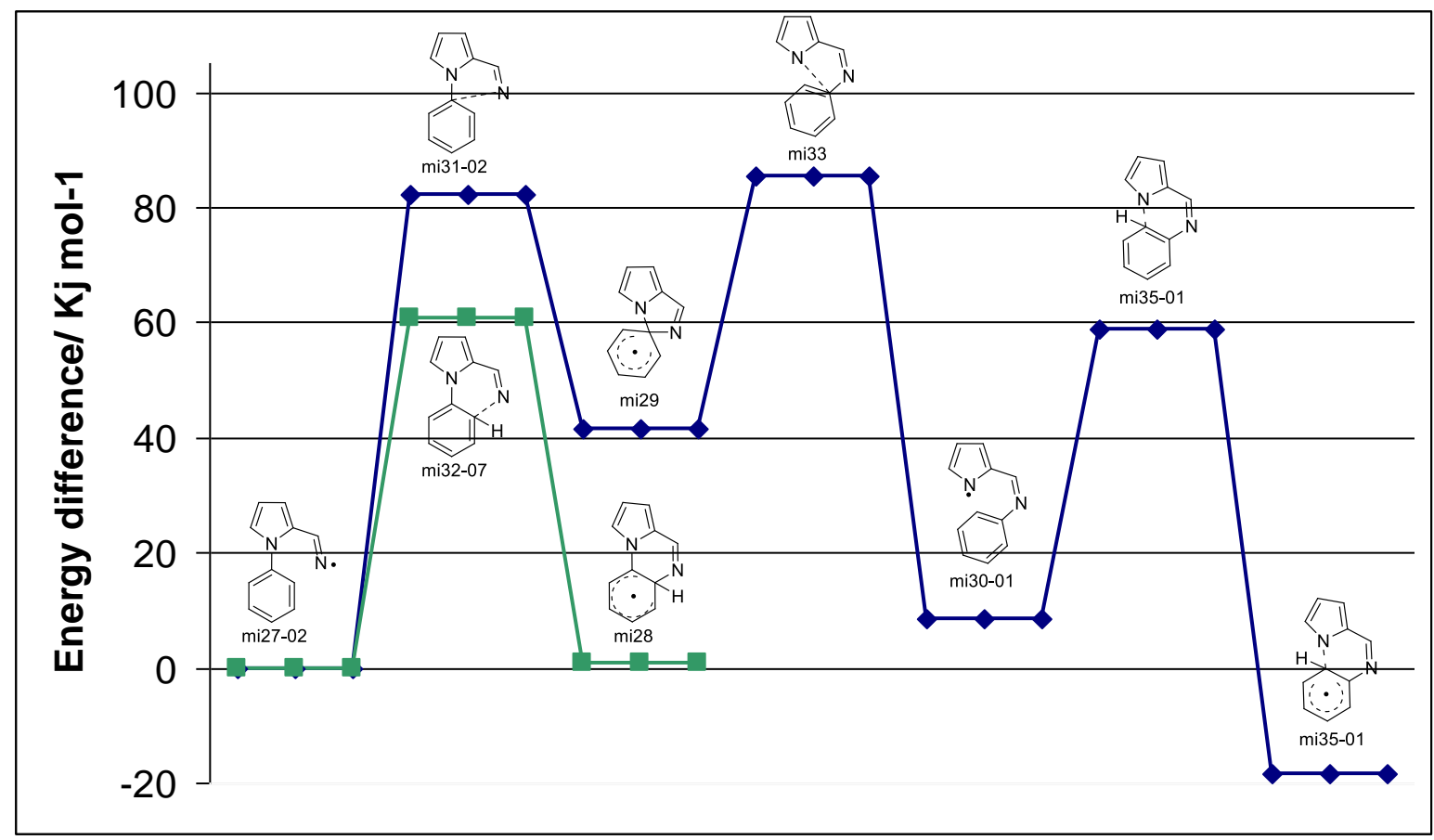

Figure 3. The iminyl $\mathbf{1}(X=N)$ - pyrrol-1-yl $\mathbf{2}(X=N)$ energy surface; codes refer to the structures given in the supplementary information.

By comparison, the difference in energy between the transition states relating the pyrrol-1-yl $2(X=C H)$, its direct cyclisation intermediate $22(X=C H)$ and the spirodienyl $\mathbf{3}(X=\mathrm{CH})$ is $55.6 \mathrm{~kJ} \mathrm{~mol}^{-1}$, in favour of the direct cyclisation. Similarly, the energy of the spirodienyl $3(X=C H)$ itself is some $72.9 \mathrm{~kJ} \mathrm{~mol}^{-1}$ higher than that of the direct cyclisation intermediate $\mathbf{2 1}(\mathrm{X}=\mathrm{CH})$. The results of the calculations clearly suggest that only one isomer is formed by FVP of 12, because direct cyclisation of the pyrrol-1-yl takes place, rather than formation of the spirodienyl and exclusive migration of the $\mathrm{C}-\mathrm{N}$ bond. Nevertheless, cleavage of the $\mathrm{C}-\mathrm{N}$ bond in the spirodienyl $3(X=C H)$, if formed, is indeed favoured over $\mathrm{C}-\mathrm{C}$ cleavage by $31.8 \mathrm{~kJ} \mathrm{~mol}^{-1}$. The very high energy of the vinyl radical $\mathbf{1}(\mathrm{X}=\mathrm{CH})$ may help to explain why no precursor of such species under FVP conditions is known.

Finally, it is worth noting that pyrrol-1-yl radicals generated by homolysis of the N-N bond, are formed as $\sigma$-radicals ${ }^{20}$ (e.g. $\sigma 23$ ) but intersystem crossing to the $\pi$-surface to give $\pi$-23 is likely to be facile. ${ }^{6}$ In practice the calculations show rather different electron density on the nitrogen in the 2 cases suggesting different character. Delocalisation of the $\pi$-radical might promote some reactivity at the 3-position of species such as 2 . In practice, whatever the electronic nature of the radical species involved, there is no doubt from the experimental results [including the very low yield of cyclisation product(s) by FVP of the 3-substituted precursor 15] that the pyrrolyl radical species behave as $\sigma$ - radicals localised on the nitrogen atom. 


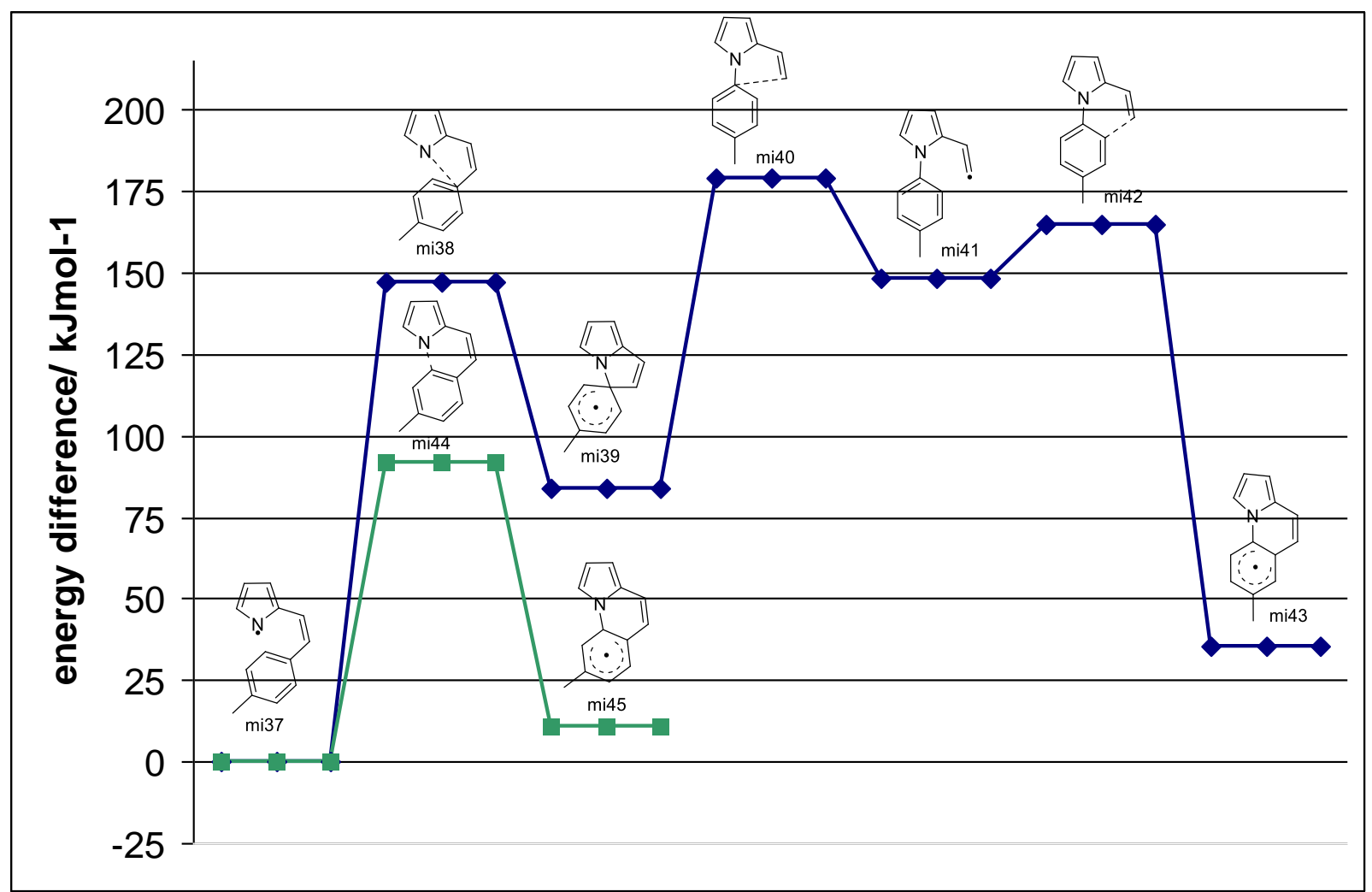

Figure 4. The vinyl $1(X=\mathrm{CH})-$ pyrrol-1-yl $\mathbf{2}(\mathrm{X}=\mathrm{CH})$ energy surface; codes refer to the structures given in the supplementary information.

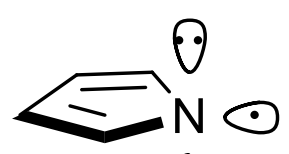

0

$\sigma \mathbf{2 3}$

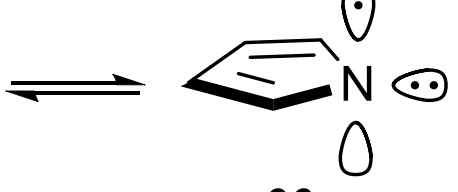

$\pi \mathbf{2 3}$

Figure 5. Representation of the $\sigma$ and $\pi$ pyrrol-1-yl radicals.

\section{Conclusions}

We conclude that FVP reactions of 1-aminopyrrole derivatives provide useful routes to pyrrol-1-yl radicals, whose cyclisation chemistry is explored here for the first time. Cyclisation of 2-vinylpyrrol-1-yls proceeds regiospecifically to provide an unusual route to the pyrrolo[1,2-a]quinoline ring system. On the other hand, cyclisation of pyrrol-1-yls containing an arylimino side chain takes place via spirodienyl radical formation and rearrangement, in competition with direct cyclisation. This result was confirmed by the cyclisation behaviour generation of an isomeric iminyl radical. Further reactions of azol-1-yl radicals will be reported in a subsequent paper. 


\section{Experimental Section}

General. ${ }^{1} \mathrm{H}$ and ${ }^{13} \mathrm{C}$ NMR spectra were recorded at 200 (or 250) and 50 (or 63 ) MHz respectively for solutions in $\left[^{2} \mathrm{H}\right]$ chloroform unless otherwise stated. Coupling constants are quoted in $\mathrm{Hz}$. Mass spectra were recorded under electron impact conditions.

1-( $p$-Tolyl)pyrrole 6. A mixture of $p$-toluidine $(4.53 \mathrm{~g}, 42.3 \mathrm{mmol}), 2,5$-dimethoxytetrahydrofuran $(6.01 \mathrm{~g}, 45$ $\mathrm{mmol})$ and glacial acetic acid $\left(20 \mathrm{~cm}^{3}\right)$ was heated under reflux for $2 \mathrm{~h}$. The volatiles were removed under reduced pressure, water $\left(100 \mathrm{~cm}^{3}\right)$ was added and the reaction mixture extracted with dichloromethane $(3 \times$ $\left.80 \mathrm{~cm}^{3}\right)$. The combined organic extracts were washed with water $\left(80 \mathrm{~cm}^{3}\right)$, dried $\left(\mathrm{MgSO}_{4}\right)$ and concentrated to give crude $6(5.71 \mathrm{~g}, 86 \%), \mathrm{mp} 77-78^{\circ} \mathrm{C}\left(\mathrm{lit}^{21}{ }^{21} 81-82{ }^{\circ} \mathrm{C}\right) \delta_{\mathrm{H}} 7.30-7.19(4 \mathrm{H}, \mathrm{m}), 7.06\left(2 \mathrm{H}, \mathrm{t},{ }^{3} \mathrm{~J} 2.2\right), 6.33\left(2 \mathrm{H}, \mathrm{t},{ }^{3} \mathrm{~J}\right.$ 2.2) and $2.37(3 \mathrm{H}, \mathrm{s}) ; \delta_{\mathrm{c}} 138.3$ (quat), 135.2 (quat), 129.9, 120.4, 119.2, 109.9 and 20.7; $\mathrm{m} / \mathrm{z} 157\left(\mathrm{M}^{+}, 100 \%\right.$ ), $115(39)$ and 91 (30).

1-( $p$-Tolyl)pyrrole-2-carbaldehyde 7. A solution of 1- $p$-tolylpyrrole $6(4.023 \mathrm{~g}, 25.6 \mathrm{mmol})$ in DMF $\left(40 \mathrm{~cm}^{3}\right)$ was added to a solution of phosphoryl chloride $(5.19 \mathrm{~g}, 33.2 \mathrm{mmol})$ in DMF $\left(85 \mathrm{~cm}^{3}\right)$ and stirred for $1 \mathrm{~h}$. A further portion of phosphoryl chloride $(5.19 \mathrm{~g}, 33.2 \mathrm{mmol})$ in DMF $\left(85 \mathrm{~cm}^{3}\right)$ was added and stirring continued for another hour. The reaction mixture was poured onto crushed ice, hydrolysed with dilute aqueous sodium hydroxide $\left(2 \mathrm{M}, 200 \mathrm{~cm}^{3}\right)$ and acidified to $\mathrm{pH} \mathrm{6-7} \mathrm{with} \mathrm{dilute} \mathrm{hydrochloric} \mathrm{acid}\left(2 \mathrm{M}, 20 \mathrm{~cm}^{3}\right)$. The mixture was then extracted with ether $\left(3 \times 250 \mathrm{~cm}^{3}\right)$ and the combined organic extracts were washed with water $\left(200 \mathrm{~cm}^{3}\right)$ and dried $\left(\mathrm{MgSO}_{4}\right)$. The solvent was removed under reduced pressure to give crude aldehyde as an orange oil. Distillation removed remaining traces of DMF and the aldehyde crystallised as an orange solid. TLC showed that formylation had occurred at both the 2- and 3-positions and so the mixture was recrystallised from light petroleum (bp $40-60{ }^{\circ} \mathrm{C}$ ) to yield only the 2-isomer 7 as white crystals $(3.30 \mathrm{~g}, 70 \%), \mathrm{mp} 54-56{ }^{\circ} \mathrm{C}$ (lit., ${ }^{22} 55^{\circ} \mathrm{C}$ ); $\delta_{\mathrm{H}} 9.55(1 \mathrm{H}, \mathrm{s}), 7.25-7.23(4 \mathrm{H}, \mathrm{m}), 7.15-7.13(2 \mathrm{H}, \mathrm{m}), 7.05-7.03(2 \mathrm{H}, \mathrm{m}), 6.38(1 \mathrm{H}, \mathrm{m})$ and $2.41(3 \mathrm{H}, \mathrm{s})$ (spectrum consistent with literature data $\left.{ }^{23}\right) ; \delta_{C} 179.0,138.1$ (quat), 136.1 (quat), 132.5 (quat), 130.9, 129.6, 125.7, 121.5, 110.6 and 21.0; $m / z 185\left(\mathrm{M}^{+}, 100 \%\right), 157(55), 128(36)$ and 92 (83).

1-p-Tolylpyrrole-2-carbaldehyde $\boldsymbol{O}$-methyloxime (8). A solution of 1-p-tolylpyrrole-2-carbaldehyde $7(0.895 \mathrm{~g}$, $4.8 \mathrm{mmol})$ and $O$-methylhydroxylamine hydrochloride $(0.822 \mathrm{~g}, 9.7 \mathrm{mmol})$ in ethanol $\left(50 \mathrm{~cm}^{3}\right)$ containing pyridine $(0.767 \mathrm{~g}, 9.7 \mathrm{mmol})$ was heated under reflux for $1 \mathrm{~h}$. Following standard work up the crude oxime ether was distilled to give 1-p-tolylpyrrole-2-carbaldehyde $O$-methyloxime 8 , bp $104-106{ }^{\circ} \mathrm{C}(0.5 \mathrm{Torr})$, that crystallised overnight to give a white solid $(0.857 \mathrm{~g}, 83 \%), \mathrm{mp} 52-53^{\circ} \mathrm{C}$ (from hexane). (Found: $\mathrm{C}, 73.15 ; \mathrm{H}$, 6.65; $\mathrm{N}, 13.1 . \mathrm{C}_{13} \mathrm{H}_{14} \mathrm{~N}_{2} \mathrm{O}$ requires $\left.\mathrm{C}, 72.9 ; \mathrm{H}, 6.55 ; \mathrm{N}, 13.1 \%\right) ; \delta_{\mathrm{H}} 7.88(1 \mathrm{H}, \mathrm{s}), 7.20(4 \mathrm{H}, \mathrm{m}), 6.88(2 \mathrm{H}, \mathrm{m}), 6.38$ $(1 \mathrm{H}, \mathrm{m}), 4.04(3 \mathrm{H}, \mathrm{s})$ and $2.42(3 \mathrm{H}, \mathrm{s}) ; \delta_{\mathrm{c}} 140.6,137.8$ (quat), 136.2 (quat), 135.8, 129.7, 126.2, 125.8, 123.6 (quat), 118.1, 62.1 and 20.8; $\mathrm{m} / \mathrm{z} 214\left(\mathrm{M}^{+}, 28 \%\right), 91$ (100) and 77 (72).

$\mathrm{N}$-(Dimethylamino)pyrrole (9). 2,5-Dimethoxytetrahydrofuran (11 g, $83 \mathrm{mmol}$ ) was added to a stirred solution of $\mathrm{N}, \mathrm{N}$-dimethylhydrazine $(5 \mathrm{~g}, 83 \mathrm{mmol})$ in acetic acid $\left(15 \mathrm{~cm}^{3}\right)$ and heated at reflux for $2.5 \mathrm{~h}$. The mixture was then quenched with sodium bicarbonate solution and extracted with dichloromethane $\left(100 \mathrm{~cm}^{3}\right)$; the organic layer was washed with water $\left(2 \times 50 \mathrm{~cm}^{3}\right)$ and then brine $\left(50 \mathrm{~cm}^{3}\right)$. The organic layer was then dried $\left(\mathrm{MgSO}_{4}\right)$ filtered and concentrated under vacuum. The residue was purified by distillation, bp $100-105{ }^{\circ} \mathrm{C}$ (15 Torr) [lit., ${ }^{24} 138-140{ }^{\circ} \mathrm{C}\left(767\right.$ Torr)], to give 9 as a pale yellow oil $(4.9 \mathrm{~g}, 54 \%)$; $\mathrm{Q}_{\mathrm{H}} 6.90\left(2 \mathrm{H}, \mathrm{d},{ }^{3} \mathrm{~J} 2.2\right), 6.08\left(2 \mathrm{H},{ }^{3} \mathrm{~J} 2.2\right)$ and $2.87(6 \mathrm{H}, \mathrm{s}) ; \delta_{\mathrm{C}} 116.2(2 \mathrm{CH}), 105.7(2 \mathrm{CH})$ and $48.3\left(2 \mathrm{CH}_{3}\right)$.

$\mathrm{N}$-(Dimethylamino)pyrrole-2-carbaldehyde (11). $\mathrm{N}, \mathrm{N}$-Dimethylformamide $\left(16.0 \mathrm{~cm}^{3}, 0.2 \mathrm{~mol}\right)$ was added to phosphorus oxychloride $\left(16.2 \mathrm{~cm}^{3}, 0.2 \mathrm{~mol}\right)$ at $10{ }^{\circ} \mathrm{C}$ over a period of $15 \mathrm{~min} .{ }^{16}$ Dichloroethane was added while allowing the mixture to reach room temperature and stirring was continued for $10 \mathrm{~min}$. A solution of the 
pyrrole $9\left(10 \mathrm{~cm}^{3}, 0.1 \mathrm{~mol}\right)$ in dichloroethane $\left(80 \mathrm{~cm}^{3}\right)$ was added dropwise over $45 \mathrm{~min}$ while stirring at $10{ }^{\circ} \mathrm{C}$. After heating under reflux for $1 \mathrm{~h}\left(95^{\circ} \mathrm{C}\right)$ the reaction reached completion and a solution of sodium acetate $(105 \mathrm{~g})$ in water $\left(210 \mathrm{~cm}^{3}\right)$ was added. After adding further water $\left(50 \mathrm{~cm}^{3}\right)$, the aqueous layer was separated and extracted with dichloromethane $\left(2 \times 200 \mathrm{~cm}^{3}\right)$. The combined organic fractions were washed with saturated sodium carbonate solution, dried $\left(\mathrm{MgSO}_{4}\right)$, filtered and concentrated. Purification was carried out by dry flash column chromatography using a gradient from $100 \%$ hexane to a 50/50 mixture of hexane and ethyl acetate. Two products were isolated: $N$-(dimethylamino)pyrrole-2-carbaldehyde 11 (7.22 g, 52\%), bp 115-120 ${ }^{\circ} \mathrm{C}$ (1.5 Torr) [lit., ${ }^{16} 84-86{ }^{\circ} \mathrm{C}\left(15\right.$ Torr)]; (Found: $\mathrm{M}^{+}$138.0794. $\mathrm{C}_{7} \mathrm{H}_{10} \mathrm{~N}_{2} \mathrm{O}$ requires $M$ 138.0793); $\delta_{\mathrm{H}} 9.76(1 \mathrm{H}, \mathrm{s})$, $7.18\left(1 \mathrm{H}, \mathrm{t},{ }^{3} \mathrm{~J} 2.5,{ }^{4} \mathrm{~J} 2.5\right), 6.91\left(1 \mathrm{H}, \mathrm{dd},{ }^{3} \mathrm{~J} 4.3,{ }^{3} \mathrm{~J} 2.5\right) 6.20\left(1 \mathrm{H}, \mathrm{dd},{ }^{3} \mathrm{~J} 4.3,{ }^{4} \mathrm{~J} 2.5\right)$ and $2.92(6 \mathrm{H}, \mathrm{s}) ; \delta_{\mathrm{C}} 179.0(\mathrm{CH})$, 130.69 (quat) $124.0(\mathrm{CH}), 117.8(\mathrm{CH}), 108.2(\mathrm{CH})$ and $47.2\left(2 \mathrm{CH}_{3}\right) ; \mathrm{m} / \mathrm{z} 138\left(\mathrm{M}^{+}, 14 \%\right)$ and $94(100): \mathrm{N}-$ (dimethylamino)pyrrole-3-carbaldehyde (1.63 g, 12\%), bp 148-150 ${ }^{\circ} \mathrm{C}(1.5 \mathrm{Torr}) ;\left(\right.$ Found: $\mathrm{M}^{+} 138.0793$. $\mathrm{C}_{7} \mathrm{H}_{10} \mathrm{~N}_{2} \mathrm{O}$ requires $M$ 138.0793); $\delta_{\mathrm{H}} 9.75(1 \mathrm{H}, \mathrm{s}), 7.84\left(1 \mathrm{H}, \mathrm{t},{ }^{4} \mathrm{~J} 2.0\right), 6.95(1 \mathrm{H}, \mathrm{m}), 6.63\left(1 \mathrm{H}, \mathrm{t},{ }^{4} \mathrm{~J} 2.0\right)$ and 2.91 $(6 \mathrm{H}, \mathrm{s}) ; \delta_{\mathrm{C}} 184.6,124.8,123.1$ (quat), $118.3,106.0$ and $47.6\left(2 \mathrm{CH}_{3}\right) ; \mathrm{m} / \mathrm{z} 138\left(\mathrm{M}^{+}, 100 \%\right)$ and $94(45)$.

$\mathbf{N}$-(Dimethylamino)pyrrol-2-ylidene]-4-methylaniline (12). $p$-Toluidine (155 $\mathrm{mg}, 1.45 \mathrm{mmol}$ ) was added to a suspension of $\mathrm{MgSO}_{4}(300 \mathrm{mg})$ and $\mathrm{N}$-(dimethylamino)pyrrole-2-carbaldehyde 11 (200 mg, $\left.1.45 \mathrm{mmol}\right)$ in toluene $\left(10 \mathrm{~cm}^{3}\right)$ and the mixture was stirred at $90{ }^{\circ} \mathrm{C}$ for $75 \mathrm{~min}$. The mixture was filtered and concentrated under vacuum before purifying by distillation to give a brown oil, which slowly solidified to give 12 (320 mg, 97\%) (Found: $\mathrm{M}^{+}, 227.1420 . \mathrm{C}_{12} \mathrm{H}_{17} \mathrm{~N}_{3}$ requires $M$ 227.1422); $\delta_{\mathrm{H}} 8.62(1 \mathrm{H}, \mathrm{s}), 7.19-7.10(5 \mathrm{H}, \mathrm{m}), 6.85\left(1 \mathrm{H}, \mathrm{dd},{ }^{3} \mathrm{~J}\right.$ $4.1,{ }^{4}$ J 1.6), $6.25\left(1 \mathrm{H}, \mathrm{dd},{ }^{3} \mathrm{~J} 4.2,2.8,{ }^{4} \mathrm{~J} 0.5\right), 2.86(6 \mathrm{H}, \mathrm{s})$ and $2.35(3 \mathrm{H}, \mathrm{s}) ; \mathrm{m} / z 227\left(\mathrm{M}^{+}, 3 \%\right), 184(67), 183(100)$, 182 (34), 91 (31) and 65 (28).

$\boldsymbol{N}$-(Dimethylamino)-2-(2-p-tolylvinyl)pyrrole (13). Sodium hydride (103mg, $4.3 \mathrm{mmol})$ was added to toluene $\left(12 \mathrm{~cm}^{3}\right)$ and stirred at $10{ }^{\circ} \mathrm{C} .{ }^{16}$ (4-Methylbenzyl)triphenylphosphonium bromide $(1.86 \mathrm{~g}, 4.3 \mathrm{mmol}$ ) was added followed by a second addition of sodium hydride (103mg, $4.3 \mathrm{mmol})$. This was stirred at $10{ }^{\circ} \mathrm{C}$ for $30 \mathrm{~min}, \mathrm{~N}$ (dimethylamino)pyrrole-2-carbaldehyde 11 (0.50 g, $3.6 \mathrm{mmol})$ was added and the mixture was heated under reflux $\left(125^{\circ} \mathrm{C}\right)$ until completion of the reaction $(3 \mathrm{~h})$. After evaporation of solvent, the residue was taken up in water $\left(50 \mathrm{~cm}^{3}\right)$ and extracted with dichloromethane $\left(2 \times 50 \mathrm{~cm}^{3}\right)$. The combined organic layers were dried $\left(\mathrm{MgSO}_{4}\right)$, filtered and the solvents evaporated. Purification by dry flash column chromatography, using hexane/ethyl acetate as eluent gave $N$-(dimethylamino)-2-(2-p-tolylvinyl)pyrrole 13 (64mg, 2.8mmol, 79\%), $\mathrm{mp}$ 60-61 ${ }^{\circ} \mathrm{C}$; (Found: $\mathrm{M}^{+}$226.1469. $\mathrm{C}_{15} \mathrm{H}_{18} \mathrm{~N}_{2}$ requires $M$ 226.1470); $\delta_{\mathrm{H}} 7.42\left(2 \mathrm{H}, \mathrm{d},{ }^{3} \mathrm{~J} 8.0\right), 7.27\left(1 \mathrm{H}, \mathrm{d},{ }^{3} \mathrm{~J} 16.0\right)$, $7.16\left(2 \mathrm{H}, \mathrm{d},{ }^{3} \mathrm{~J} 8.0\right), 7.00(1 \mathrm{H}, \mathrm{m}), 6.97\left(1 \mathrm{H}, \mathrm{d},{ }^{3} \mathrm{~J} 16.0\right), 6.35(1 \mathrm{H}, \mathrm{m}), 6.21(1 \mathrm{H}, \mathrm{m}), 2.85(6 \mathrm{H}, \mathrm{s})$ and $2.38(3 \mathrm{H}, \mathrm{s})$; $\delta_{\mathrm{C}} 136.4$ (quat), 135.3 (quat), 130.8 (quat), $129.1(2 \mathrm{CH}), 125.8(2 \mathrm{CH}), 125.1,116.2,113.4,107.6,102.03,47.7$ $\left(2 \mathrm{CH}_{3}\right)$ and $21.1\left(\mathrm{CH}_{3}\right) ; \mathrm{m} / \mathrm{z} 226\left(\mathrm{M}^{+}, 73 \%\right)$ and $183(100)$.

$\mathbf{N}$-(Dimethylamino)-3-(2-p-tolylvinyl)pyrrole (15). Synthesised as above for $\mathbf{1 3}$, from $\mathrm{N}$-(dimethylamino)pyrrole-3-carbaldehyde 14 in $60 \%$ yield, $\mathrm{N}$-(dimethylamino)-3-(2-p-tolylvinyl)pyrrole 15 had mp $70{ }^{\circ} \mathrm{C}$; (Found: $\mathrm{M}^{+}$226.1469. $\mathrm{C}_{15} \mathrm{H}_{18} \mathrm{~N}_{2}$ requires $M$ 226.1470); $\delta_{\mathrm{H}} 7.34\left(2 \mathrm{H}, \mathrm{d},{ }^{3} \mathrm{~J} 8.1\right), 7.13\left(2 \mathrm{H}, \mathrm{d},{ }^{3} \mathrm{~J} 8.1\right), 6.97(1 \mathrm{H}, \mathrm{m}), 6.94(1 \mathrm{H}$, $\left.\mathrm{d},{ }^{3} \mathrm{~J} 16.5\right), 6.84\left(1 \mathrm{H}, \mathrm{t},{ }^{3} \mathrm{~J} 2.8\right), 6.75\left(1 \mathrm{H}, \mathrm{d},{ }^{3} \mathrm{~J} 16.5\right), 6.31\left(1 \mathrm{H}, \mathrm{t},{ }^{3} \mathrm{~J} 2.8\right), 2.85(6 \mathrm{H}, \mathrm{s})$ and $265(3 \mathrm{H}, \mathrm{s}) ; \delta_{\mathrm{C}} 136.0$ (quat), 135.4 (quat), $129.1(2 \mathrm{CH}), 125.51(2 \mathrm{CH}), 124.2(\mathrm{CH}), 121.2(\mathrm{CH}), 120.5$ (quat), $117.8(\mathrm{CH}), 115.6(\mathrm{CH})$, $103.1(\mathrm{CH}), 48.2\left(2 \mathrm{CH}_{3}\right)$ and $21.0\left(\mathrm{CH}_{3}\right) ; \mathrm{m} / z 226\left(\mathrm{M}^{+}, 100 \%\right)$ and $167(66)$.

\section{Flash Vacuum Pyrolysis Experiments}

Conditions for the pyrolyses were established in small scale experiments in which the products were dissolved in a deuteriated solvent and analysed immediately by ${ }^{1} \mathrm{H}$ NMR spectroscopy. On a larger scale the crude products were separated by flash column chromatography unless otherwise stated. The conditions [precursor 
quantity, furnace temperature $\left(T_{f}\right)$, inlet temperature $\left(T_{i}\right)$, pressure range $(P)$, and pyrolysis time $(t)$ ] are provided individually for each reaction.

FVP of 1-p-tolylpyrrole-2-carbaldehyde 0 -methyloxime (8). FVP of 1- $p$-tolylpyrrole-2-carbaldehyde- $O$ methyloxime 8 was carried out on $0.1 \mathrm{mmol}(25 \mathrm{mg})$ scale to identify the optimum conditions $\left(\mathrm{T}_{\mathrm{i}} 75-105^{\circ} \mathrm{C}, \mathrm{T}_{\mathrm{f}}\right.$ 500-650 ${ }^{\circ} \mathrm{C}, \mathrm{P} 1.8 \times 10^{-2}$ Torr, $20 \mathrm{~min}$ ). The composition of the resulting mixture showed: $500{ }^{\circ} \mathrm{C}, 15 \%$ of 8 converted, $550{ }^{\circ} \mathrm{C}, 43 \% ; 575{ }^{\circ} \mathrm{C}, 71 \% ; 600{ }^{\circ} \mathrm{C}, 90 \%$; $650{ }^{\circ} \mathrm{C}, 94 \%$. Formation of the iminyl was essentially complete at $6500^{\circ} \mathrm{C}$ and this temperature was chosen for preparative pyrolysis.

Thus, FVP of 8 [0.437 $\mathrm{g}(2.0 \mathrm{mmol}), \mathrm{T}_{\mathrm{i}} 75-105{ }^{\circ} \mathrm{C}, \mathrm{T}_{\mathrm{f}} 650{ }^{\circ} \mathrm{C}, \mathrm{P} 1.2 \times 10^{-2}$ Torr, $\mathrm{t} 30 \mathrm{~min}$ ] provided 7methylpyrrolo[1,2-a]quinoxaline 16 (0.172 g, 40\%) (Found: 182.08442; $\mathrm{C}_{12} \mathrm{H}_{10} \mathrm{~N}_{2}$ requires $\left.M, 182.08440\right)$; 目 $8.77(1 \mathrm{H}, \mathrm{s}), 7.88-7.71(3 \mathrm{H}, \mathrm{m}), 7.32(1 \mathrm{H}, \mathrm{m}), 6.87-6.85(2 \mathrm{H}, \mathrm{m})$ and $2.48(3 \mathrm{H}, \mathrm{s}) ; \delta_{\mathrm{c}} 145.5,135.4$ (quat), 134.9 (quat), 129.7, 128.8, 126.2 (quat), 125.7 (quat), 113.9, 113.7, 113.4, 107.0 and 21.0 (spectra consistent with literature data $\left.{ }^{25}\right) ; \mathrm{m} / \mathrm{z} 182\left(\mathrm{M}^{+}, 100 \%\right), 127$ (7) and 90 (14): 8-methylpyrrolo[1,2-a]quinoxaline 17 (0.175 g, 41\%) (Found: 182.0843. $\mathrm{C}_{12} \mathrm{H}_{10} \mathrm{~N}_{2}$ requires $\left.M, 182.0844\right) ; \delta_{\mathrm{H}} 8.74(1 \mathrm{H}, \mathrm{s}), 7.91(1 \mathrm{H}, \mathrm{m}), 7.87\left(1 \mathrm{H}, \mathrm{d},{ }^{3} \mathrm{~J} 8.2\right), 7.68$ $(1 \mathrm{H}, \mathrm{s}), 7.29\left(1 \mathrm{H}, \mathrm{dd},{ }^{3} \mathrm{~J} 8.2,{ }^{4} \mathrm{~J} 0.6\right), 6.90-6.88(2 \mathrm{H}, \mathrm{m})$ and $2.58(3 \mathrm{H}, \mathrm{s}) ; \delta_{\mathrm{C}} 144.7,138.2$ (quat), 133.5 (quat), $129.5,128.8$ (quat), 127.6 (quat), 126.3, 113.8, 113.7, 113.4, 106.9 and 21.6; $\mathrm{m} / \mathrm{z} 182\left(\mathrm{M}^{+}, 100 \%\right), 91(10)$ and 63 (4): 1-p-tolylpyrrole-2-carbonitrile $18(0.028 \mathrm{~g}, 8 \%)$ (Found: $182.0842 . \mathrm{C}_{12} \mathrm{H}_{10} \mathrm{~N}_{2}$ requires $\left.M, 182.0844\right) ; \delta_{\mathrm{H}}$ 7.34-7.28 $(4 \mathrm{H}, \mathrm{m}), 7.04(1 \mathrm{H}, \mathrm{m}), 6.97(1 \mathrm{H}, \mathrm{m}), 6.32(1 \mathrm{H}, \mathrm{m})$ and $2.41(3 \mathrm{H}, \mathrm{s}) ; \delta_{\mathrm{c}} 138.3$ (quat), 135.6 (quat), $130.0,126.8,123.9,121.8,113.8$ (quat), 110.3, 103.9 and 20.9 (spectra consistent with literature data ${ }^{26}$ ); $m / z$ $182\left(\mathrm{M}^{+}, 100 \%\right), 91(14)$ and 65 (9): 1-p-tolylpyrrole $6(0.018 \mathrm{~g}, 5 \%), \delta_{\mathrm{H}} 7.30-7.18(4 \mathrm{H}, \mathrm{m}), 7.05\left(2 \mathrm{H}, \mathrm{t},{ }^{3} \mathrm{~J}\right.$ and ${ }^{4} \mathrm{~J}$ 2.2), $6.34\left(2 \mathrm{H}, \mathrm{t},{ }^{3} \mathrm{~J}\right.$ and $\left.{ }^{4} \mathrm{~J} 2.2\right)$ and $2.37(3 \mathrm{H}, \mathrm{s}) ; \delta_{\mathrm{C}} 138.3$ (quat), 135.2 (quat), 129.9, 120.4, 119.3, 109.9 and 20.7 [spectra consistent with those of an authentic sample (see earlier Experimental details)].

FVP of $\mathbf{N}$-(dimethylamino)pyrrole 9 - temperature profile. Due to its low boiling point $\left(138-140{ }^{\circ} \mathrm{C}\right.$ at atmospheric pressure) $\mathrm{N}$-(dimethylamino)pyrrole $\mathbf{9}$ was frozen in the inlet system using an acetone/dry ice bath which remained in place around the inlet as the vacuum was applied. The cooling bath was then slowly removed allowing the $\mathrm{N}$-(dimethylamino)pyrrole 9 to volatilise into the furnace tube in a controlled manner.

$\boldsymbol{T}_{\mathrm{f}} \mathbf{5 5 0}{ }^{\circ} \mathrm{C}$, (24.8 mg, $T_{\mathrm{i}} \mathrm{RT}, P 2.3-2.4 \times 10^{-2} \mathrm{Torr}, t 16 \mathrm{~min}$ ) gave $N$-(dimethylamino)pyrrole $\mathbf{9}$ (ca $97 \%$ )

$T_{\mathrm{f}} 600{ }^{\circ} \mathrm{C},\left(21.5 \mathrm{mg}, T_{\mathrm{i}} \mathrm{RT}, P 2.4-3.0 \times 10^{-2} \mathrm{Torr}, t 17 \mathrm{~min}\right.$ ) gave $\mathrm{N}$-(dimethylamino)pyrrole 9 (ca $\left.92 \%\right)$ and pyrrole 10 (ca $8 \%)$

$\boldsymbol{T}_{\mathrm{f}} 650{ }^{\circ} \mathrm{C},\left(21.3 \mathrm{mg}, T_{\mathrm{i}} \mathrm{RT}, P 2.6-3.5 \times 10^{-2} \mathrm{Torr}, t 16 \mathrm{~min}\right.$ ) gave $\mathrm{N}$-(dimethylamino)pyrrole 9 (ca 63\%) and pyrrole 10 (ca 37\%)

$\boldsymbol{T}_{\mathrm{f}} 700{ }^{\circ} \mathrm{C},\left(21.6 \mathrm{mg}, T_{\mathrm{i}} \mathrm{RT}, P 2.6-3.2 \times 10^{-2} \mathrm{Torr}, t 15 \mathrm{~min}\right.$ ) gave $\mathrm{N}$-(dimethylamino)pyrrole $\mathbf{9}$ (ca $\left.21 \%\right)$ and pyrrole 10 (ca 79\%)

$\boldsymbol{T}_{\mathrm{f}} 750^{\circ} \mathrm{C}$, (24.3 $\mathrm{mg}, T_{\mathrm{i}} \mathrm{RT}, P 2.8-5.0 \times 10^{-2} \mathrm{Torr}, t 17 \mathrm{~min}$ ) gave $\mathrm{N}$-(dimethylamino)pyrrole 9 (ca $\left.18 \%\right)$ and pyrrole 10 (ca 82\%)

$T_{\mathrm{f}} 800{ }^{\circ} \mathrm{C}$, (24.6 mg, $T_{\mathrm{i}} \mathrm{RT}, P 2.5-6.0 \times 10^{-2}$ Torr, $t 16 \mathrm{~min}$ ) gave $\mathrm{N}$-(dimethylamino)pyrrole 9 (ca $3 \%$ ) and pyrrole 10 (ca $97 \%)$

$T_{\mathrm{f}} 850^{\circ} \mathrm{C}$, (25.5 mg, $T_{\mathrm{i}} \mathrm{RT}, P 3.2-7.3 \times 10^{-2}$ Torr, $t 19 \mathrm{~min}$ ) gave pyrrole 10 (ca 99\%).

FVP of $\boldsymbol{N}$-[dimethylamino)pyrrol-2-ylidene]-4-methylaniline (12). FVP of $\mathrm{N}$-[dimethylamino)pyrrol-2-ylidene]4-methylaniline 12 [(20 mg, $0.1 \mathrm{mmol}), \mathrm{T}_{\mathrm{i}} 74-106^{\circ} \mathrm{C}, \mathrm{T}_{\mathrm{f}} 800{ }^{\circ} \mathrm{C}, 1.6 \times 10^{-2} \mathrm{Torr}, 45 \mathrm{~min}$ ] gave a mixture of only 7methylpyrrolo[1,2-a]quinoxaline 16 and 8-methylpyrrolo[1,2-a]quinoxaline 17 in a 1:3 ratio (27\% of 16 : 73\% of 17) (spectroscopic data as above).

FVP of $\mathbf{N}$-(dimethylamino)-2-(2-p-tolylvinyl)pyrrole (13). FVP of $\mathbf{N}$-(dimethylamino)-2-(2- $p$-tolylvinyl)pyrrole 13 [108 mg (0.48 mmol) $\mathrm{T}_{\mathrm{f}} 750{ }^{\circ} \mathrm{C}, \mathrm{T}_{\mathrm{i}} 140{ }^{\circ} \mathrm{C}, P$ 2.6-14 $\left.\times 10^{-2} \mathrm{Torr}, t 1 \mathrm{~h}\right)$ gave 8-methylpyrrolo[1,2-a]quinoline 19 (43 mg, 50\%), (Found: $\mathrm{M}^{+}$181.0891. $\mathrm{C}_{13} \mathrm{H}_{11} \mathrm{~N}$ requires $M$ 181.0892); $\delta_{\mathrm{H}} 7.71(1 \mathrm{H}, \mathrm{s}, \mathrm{H}-8), 7.54\left(1 \mathrm{H}, \mathrm{d},{ }^{3} \mathrm{~J} 7.9\right.$, 
H-6), 7.34 (1H, m, H-1), $7.27\left(1 \mathrm{H}, \mathrm{d},{ }^{3}\right.$ J 9.3, H-4), $7.15\left(1 \mathrm{H}, \mathrm{d},{ }^{3} \mathrm{~J} 7.9, \mathrm{H}-7\right), 6.97\left(1 \mathrm{H}, \mathrm{d},{ }^{3} \mathrm{~J} 9.3, \mathrm{H}-5\right), 6.80\left(1 \mathrm{H}, \mathrm{t},{ }^{3} \mathrm{~J}\right.$ 3.2, $\mathrm{H}-2), 6.52(1 \mathrm{H}, \mathrm{m}, \mathrm{H}-3)$ and $2.56(3 \mathrm{H}, \mathrm{s}, \mathrm{Me}) ; \delta_{\mathrm{C}} 137.9$ (quat), 133.2 (quat), 131.0 (quat), 128.2, 124.7, 121.3 (quat), 118.5, 117.8, 114.2, 112.4, 111.5, 102.2 and 21.8 (Me); $m / z 181\left(\mathrm{M}^{+}, 100 \%\right)$.

FVP of $\boldsymbol{N}$-dimethylamino-3-(2-p-tolylvinyl)pyrrole (15). FVP of $\mathbf{N}$-dimethylamino-3-(2-p-tolylvinyl)pyrrole 15 [116 mg (0.51 mmol) $\mathrm{T}_{\mathrm{f}} 750{ }^{\circ} \mathrm{C}, \mathrm{T}_{\mathrm{i}} 140{ }^{\circ} \mathrm{C}, P 2.1-10 \times 10^{-2}$ Torr, $\mathrm{t} 1 \mathrm{~h}$ ) gave a mixture of products: 8methylpyrrolo[1,2-a]quinoline $19(4.6 \mathrm{mg}, 5 \%) ; \delta_{\mathrm{H}} 7.71(1 \mathrm{H}, \mathrm{s}), 7.54\left(1 \mathrm{H}, \mathrm{d},{ }^{3} \mathrm{~J} 7.9\right), 7.34(1 \mathrm{H}, \mathrm{m}), 7.27\left(1 \mathrm{H}, \mathrm{d},{ }^{3} \mathrm{~J}\right.$ 9.3), $7.15\left(1 \mathrm{H}, \mathrm{d},{ }^{3} \mathrm{~J} 7.9\right), 6.97\left(1 \mathrm{H}, \mathrm{d},{ }^{3} \mathrm{~J} 9.3\right), 6.80\left(1 \mathrm{H}, \mathrm{t},{ }^{3} \mathrm{~J} 3.2\right), 6.52(1 \mathrm{H}, \mathrm{m})$ and $2.56(3 \mathrm{H}, \mathrm{s}): 3-(2-p-$ tolylvinyl)pyrrole 20 (10.3 mg, 11\%) (Found: $\mathrm{M}^{+}$183.1047. $\mathrm{C}_{13} \mathrm{H}_{13} \mathrm{~N}$ requires $M$ 183.1048); $\delta_{\mathrm{H}} 8.16(1 \mathrm{H}, \mathrm{br} . \mathrm{s})$, $7.37\left(2 \mathrm{H}, \mathrm{d},{ }^{3} J\right.$ 8.1), $7.15\left(2 \mathrm{H}, \mathrm{d},{ }^{3} J \mathrm{~J} 8.1\right), 7.04\left(1 \mathrm{H}, \mathrm{d},{ }^{3} \mathrm{~J} 16.2\right), 6.90\left(1 \mathrm{H}, \mathrm{dd},{ }^{3} J 4.2\right), 6.81\left(1 \mathrm{H}, \mathrm{d},{ }^{3} J 16.2\right), 6.80(1 \mathrm{H}$, $\left.\mathrm{dd},{ }^{4} \mathrm{~J} 2.6\right), 6.51\left(1 \mathrm{H}, \mathrm{dd},{ }^{3} \mathrm{~J} 4.2,{ }^{4} \mathrm{~J} 2.6\right)$ and $2.36(3 \mathrm{H}, \mathrm{s}) ; \delta_{\mathrm{C}} 136.04$ (quat), 135.40 (quat), 129.12 (2CH), 125.56 $(2 \mathrm{CH}), 124.60(\mathrm{CH}), 123.10$ (quat), $121.20(\mathrm{CH}), 119.01(\mathrm{CH}), 117.12(\mathrm{CH}), 105.45(\mathrm{CH})$ and $20.82\left(\mathrm{CH}_{3}\right)(\mathrm{spectra}$ consistent with literature data $\left.{ }^{27}\right) ; \mathrm{m} / z 183\left(\mathrm{M}^{+}, 100 \%\right)$ : a fraction which was tentatively identified as impure 8methylbenzo[g]indole S1 (trace) (Found: $\mathrm{M}^{+} 181.0891 . \mathrm{C}_{13} \mathrm{H}_{11} \mathrm{~N}$ requires $\left.M 181.0892\right) ; \delta_{\mathrm{H}} 9.01(1 \mathrm{H}, \mathrm{br} . \mathrm{s}), 7.85-$ $7.80(2 \mathrm{H}, \mathrm{m}), 7.67\left(1 \mathrm{H}, \mathrm{d},{ }^{3} \mathrm{~J} 8.5\right), 7.49\left(1 \mathrm{H}, \mathrm{d},{ }^{3} \mathrm{~J} 8.5\right), 7.36-7.13(2 \mathrm{H}, \mathrm{m}), 6.12(1 \mathrm{H}, \mathrm{m})$ and $2.39(3 \mathrm{H}, \mathrm{s}) ; \mathrm{m} / z 181$ $\left(\mathrm{M}^{+}, 100 \%\right)$ and $84(92)$.

Formation of products from FVP of $\mathbf{N}$-dimethylamino-3-(2-p-tolylvinyl)pyrrole (15). Three products were isolated, in low yield, from FVP of 15. The product of hydrogen-capture by the pyrrol-1-yl radical, 20, retains the carbon skeleton of the precursor. Similarly, the formation of 8-methylbenzo[g]indole S1, tentatively identified in trace amounts from an impure fraction, is consistent with delocalisation of the pyrrol-1-yl radical to the 2-position, followed by cyclisation. Clearly this is not a favourable process for the initial radical. Finally the formation of 8-methylpyrrolo[1,2-a]quinoline 19 requires rearrangement of the vinyl group from the 3position to the 2-position of the pyrrole, followed by cyclisation. Such 1,5-shifts are well-known in the thermal chemistry of pyrroles, ${ }^{15}$ and although the rearrangement is not normally quantitative at temperatures as low as $750{ }^{\circ} \mathrm{C}$ in our apparatus, they may well account for the formation of such a minor product (5\%).

\section{Acknowledgements}

We are grateful to EaStCHEM and EPSRC for Research Studentships (for M. I. and E. J. R., respectively) and The University of Edinburgh for funding. This work has made use of the resources provided by the EaStCHEM Research Computing Facility (http://www.eastchem.ac.uk/rcf) and we are grateful to Dr. Patricia Richardson for assistance. The facility is partially supported by the eDIKT initiative (http://www.edikt.org.).

\section{Supplementary Material}

Results of DFT calculations are available in the Supplementary Material file associated with this paper. 


\section{References}

"Deceased $15^{\text {th }}$ November 2010

1. Cadogan, J. I. G.; Hickson, C. L.;McNab, H. Tetrahedron 1986, 42, 2135-2165.

https://doi.org/10.1016/50040-4020(01)90594-0

2. McNab, H. J. Chem. Soc., Perkin Trans. 1 1984, 371-376.

https://doi.org/10.1039/p19840000371

3. McNab, H.; Smith, G. S. J. Chem. Soc., Perkin Trans. 1 1984, 381-384.

https://doi.org/10.1039/p19840000381

4. Hickson, C. L.; McNab, H. J. Chem. Soc., Perkin Trans. 1 1984, 1569-1572. https://doi.org/10.1039/p19840001569

5. Gritter, R. J.; Chriss, R. J. J. Org. Chem. 1964, 29, 1163-1167. https://doi.org/10.1021/j001028a041

6. Blinder, S. M.; Peller, M. L.; Lord,N. W.; Aamodt, L. C.; Ivanchukov, N. S. J. Chem. Phys. 1962, 36, 540-544 https://doi.org/10.1063/1.1732546

7. Blank, D. A.; North, S. W.; Lee, Y. T. Chem. Phys. 1994, 187, 35-47; https://doi.org/10.1016/0301-0104(94)00230-4

8. Gianola, A. J.; Ichino, T.; Hoenigman, R. L.; Kato, S.; Bierbaum, V. M.; Lineberger, W. C. J. Phys. Chem A 2004, 108, 10326-10335. https://doi.org/10.1021/ip047790+

9. Bacskay, G. B.; Martoprawiro, M.; Mackie, J. C. Chem. Phys. Lett. 1998, 290, 391-398. https://doi.org/10.1016/50009-2614(98)00558-2

10. Fadden, M. J.; Hadad, C. M. J. Phys. Chem A 2000, 104, 6324-6331. https://doi.org/10.1021/jp0012202

11. Luo, H.; Lin, M. C. Phys. Lett. 2001, 343, 219-224. https://doi.org/10.1016/50009-2614(01)00711-4

12. da Silva, G.; Moore, E. E.; Bozzelli, J. W. J. Phys. Chem A 2006, 110, 13979-13988. https://doi.org/10.1021/ip065150w

13. Qiu, Y.-Q.; Fan, H.-L.; Sun, S.-L.; Liu, C.-G.; Su, Z.-M. J. Phys. Chem A 2008, 112, 83-88. https://doi.org/10.1021/ip073907t

14. Bovy, P. R.; Reitz, J. D. B.; Collins, J. T.; Chamberlain, T. S.; Olins, G. M.; Corpus, V. M.; McMahon, E. G.; Palomo, M. A.; Koepke, J. P.; Smits, G. J.; McGraw, D. E.; Gawt, J. F. J. Med. Chem., 1993, 36, 101-110. https://doi.org/10.1021/im00053a013

15. Patterson, J. M. Synthesis 1976, 281-304. https://doi.org/10.1055/s-1976-24021

16. Hinz, W.; Jones, R. A.; Anderson, T. Synthesis 1986, 620-623. https://doi.org/10.1055/s-1986-31722

17. Hickson, C. L.; McNab, H. J. Chem.Res. (S) 1989, 176-177.

18. Ogawa,K. Eur. Pat. Appl. EP 575923, 1993. Chem Abstr.1994, 120, 245118

19. Frisch, M. J.; Trucks, G. W.; Schlegel, H. B.; Scuseria, G. E.; Robb, M. A.; Cheeseman, J.R.; Montgomery, J. A. Jr.; Vreven, T.; Kudin, K. N.; Burant, J. C.; Millam, J. M.; Iyengar, S. S.; Tomasi, J.; Barone, V.; Mennucci, B.; Cossi, M.; Scalmani, G.; Rega, N.; Petersson, G. A.; Nakatsuji, H.;Hada, M.; Ehara, M.; Toyota, K.; Fukuda, R.; Hasegawa, J.; Ishida, M.; Nakajima, T.; Honda, Y.; Kitao, O.; Nakai, H.; Klene, M.; Li, X.; Knox, J. 
E.; Hratchian, H. P.; Cross, J. B.;Bakken, V.;Adamo, C.;Jaramillo, J.;Gomperts, R.;Stratmann, R. E.; Yazyev, O.;Austin, A. J.;Cammi, R.; Pomelli, C.; Ochterski, J. W.;Ayala, P. Y.; Morokuma, K.;Voth, G. A.; Salvador, P.;Dannenberg, J. J.; Zakrzewski, V. G.; Dapprich, S.;Daniels, A. D.; Strain, M. C.; Farkas, O.; Malick, D. K.; Rabuck, A. D.; Raghavachari, K.; Foresman, J. B.; Ortiz, J. V.; Cui, Q.; Baboul, A. G.; Clifford, S.; Cioslowski, J.; Stefanov, B. B.; Liu, G.; Liashenko, A.; Piskorz, P.;Komaromi, I.; Martin, R. L.; Fox, D. J.; Keith, T.;AlLaham, M. A.; Peng, C. Y.; Nanayakkara, A.; Challacombe, M.; Gill, P. M. W.; Johnson, B.; Chen, W.; Wong, M. W.; Gonzalez, C.; Pople, J. A. Gaussian03; Gaussian, Inc., Wallingford CT, 2004.

20. de Mendoza, J.; Millan, C.; Rull, P. J. Chem. Soc., Perkin Trans. 1 1981, 403-407. https://doi.org/10.1039/P19810000403

21. Huntress, E. H.; Leslie T. E.; Hearon, W. M. J. Am. Chem. Soc., 1956 78, 419-423. https://doi.org/10.1021/ja01583a046

22. Candy, C. F.; Jones, R. A.; Wright, P. H. J. Chem. Soc. (C) 1970, 2563-2567. https://doi.org/10.1039/J39700002563

23. D’arcy, B. R.; Lewis, K. G.; Mulquiney, C. E. Aust. J. Chem. 1985, 38, 953-965. https://doi.org/10.1071/CH9850953

24. Martinez, G. R.; Grieco, P. R.; Srinivasan, G. V. J. Org. Chem. 1981, 46, 3760-3761. https://doi.org/10.1021/jo00331a047

25. Cobb, J.; Cheeseman, G. W. H. Magn. Reson. Chem. 1986, 24, 231-238.

26. Liu, W.; Ma, Y.; Yin, Y.-W.; Zhao, Y.-F. J. Heterocycl. Chem. 2006, 43, 681-684. https://doi.org/10.1002/jhet.5570430322 